\title{
IMMUNITY TO HAEMOPHILUS INFLUENZAE TYPE B : THE ROLE OF THE CAPSULAR ANTIBODY
}

\author{
Y. MPAIRWE* \\ Department of Medical Microbiology, Makerere University, \\ Kampala, Uganda
}

IT is believed that the protective antibody against Haemophilus influenzae type $b$ is that produced against its capsular antigen (Alexander, 1965; MacLeod and Bernheimer, 1965; Davis et al., 1967). If this is so we should expect the age-distribution of this capsular antibody to resemble that of the bactericidal factor in the blood against the causative organism (Fothergill and Wright, 1933 ) and to be inversely related to that of $H$. influenzae type-b infections.

In the present study the frequency of the capsular antibody and the bactericidal factor at various ages was determined. The purpose of this paper is to report that they were found to be dissimilar, and to suggest that the belief that immunity to $H$. influenzae type-b infections is due to capsular antibody may be incorrect.

\section{MATERIALS AND METHODS}

Serum samples were obtained from the blood collected aseptically from patients in Mulago Hospital, Kampala, who were not on antibiotic treatment. Their ages ranged from birth (cord blood) to adulthood. Sera were stored at $-20^{\circ} \mathrm{C}$ and used within 4 wk of collection.

The $H$. influenzae type b strain used was isolated from cerebrospinal fluid. It formed iridescent colonies on Levinthal's agar and was agglutinated by type-b antiserum (Burroughs Wellcome \& Co.) and was not agglutinated by antisera against any other types. Diluent for emulsifying $H$. influenzae type b in bactericidal tests was 10 per cent. normal rabbit or bovine serum (previously heated at $56^{\circ} \mathrm{C}$ for $30 \mathrm{~min}$.) in saline. "Suspension -4 " used in studies of the bactericidal factor, was made by emulsifying, in $5 \mathrm{ml}$ of diluent, two colonies of $H$. influenzae type b from an 18-hr culture on chocolate agar and transferring $0.1 \mathrm{ml}$ of this emulsion into $0.9 \mathrm{ml}$ of diluent. From this, further dilutions in diluent were made to $10^{-4}$. Drops $(0.02 \mathrm{ml})$ were those delivered by a calibrated Pasteur pipette.

Capsular antibody was detected by the haemagglutination technique of Turk and Green (1964). Sera were tested at two-fold dilutions in saline from undiluted to 1 in 64 inclusive. Sera in which antibody was detected at any titre were recorded as positive. The bactericidal factor was detected as follows. One drop of " suspension -4 " was added to $0.2 \mathrm{ml}$ of the test serum in a screw-capped $5-\mathrm{ml}$ bottle. This was shaken gently and incubated at $37^{\circ} \mathrm{C}$ in a waterbath for $45 \mathrm{~min}$. At the end of this period it was shaken again and a drop plated on to chocolate agar and incubated for $18-24 \mathrm{hr}$ at $37^{\circ} \mathrm{C}$. Plates were then examined for growth, and serum samples from which there was no growth were recorded as positive for bactericidal factor.

\section{RESULTS}

The capsular antibody was looked for in 132 subjects and its age-distribution in them is shown in the table. It was uncommon in all age-groups below $5 \mathrm{yr}$

Received 18 Feb. 1970; accepted 4 May 1970.

* Present address: Department of Clinical Pathology, University College Hospital, London, W.C.1.

J. MED. MICROBIOL.-VOL. 4 (1971) 
including newborn babies, and was detected in only 30 per cent. of subjects over the age of $5 \mathrm{yr}$. The bactericidal factor was looked for in a smaller number of subjects. It was possessed by a large proportion of newborn babies and of subjects over $5 \mathrm{yr}$ of age, but it was absent or uncommon in age-groups between $2 \mathrm{mth}$ and $5 \mathrm{yr}$ (table).

\section{Discussion}

The age-distribution of Haemophilus influenzae meningitis was shown by Fothergill and Wright (1933) to be inversely related to that of a bactericidal factor against the causative organism found in the blood. This finding was used to support their hypothesis that immunity in the newborn is acquired from the mother transplacentally, lost within the first few weeks of birth and gradually built up through inapparent infection, immunity generally being poorly

TABLE

Age-distribution of capsular and bactericidal antibodies against Haemophilus influenzae type $b$

\begin{tabular}{|c|c|c|c|c|}
\hline \multirow[b]{2}{*}{$\begin{array}{c}\text { Age of } \\
\text { serum donor }\end{array}$} & \multicolumn{4}{|c|}{ Number of sera } \\
\hline & $\begin{array}{l}\text { examined for } \\
\text { capsular } \\
\text { antibody }\end{array}$ & $\begin{array}{c}\text { containing } \\
\text { capsular } \\
\text { antibody } \\
\text { (with percentage) }\end{array}$ & $\begin{array}{l}\text { examined for } \\
\text { bactericidal } \\
\text { antibody }\end{array}$ & $\begin{array}{c}\text { containing } \\
\text { bactericidal } \\
\text { antibody } \\
\text { (with percentage) }\end{array}$ \\
\hline $\begin{array}{l}\text { At birth } \\
2 \mathrm{mth}-2 \mathrm{yr} \\
2-5 \mathrm{yr} \\
\text { Over } 5 \mathrm{yr}\end{array}$ & $\begin{array}{l}31 \\
43 \\
28 \\
30\end{array}$ & $\begin{array}{l}1(3) \\
0(0) \\
2(8) \\
9(30)\end{array}$ & $\begin{array}{r}8 \\
11 \\
10 \\
13\end{array}$ & $\begin{array}{c}7(88) \\
0(0) \\
4(40) \\
11(85)\end{array}$ \\
\hline
\end{tabular}

developed before the age of 3-4 yr. This explanation for the now well-known age incidence of $H$. influenzae type $\mathrm{b}$ infections has been generally accepted (e.g., Weinstein, 1946; Smith, 1956; Mathies, Hodgman and Ivler, 1965; Jawetz, Melnick and Adelberg, 1966; Collier, Connor and Nyhan, 1967).

It has also been stated, however, that the protective antibody against $H$. influenzae type $\mathrm{b}$ is that produced against its capsular antigen (Alexander, 1965; MacLeod and Bernheimer, 1965; Davis et al., 1967). But if this were so, the age-distribution of the capsular antibody would be expected to be, like that of the bactericidal factor, inversely related to that of $H$. influenzae type $b$ infections. To the best of my knowledge, this has not been reported to be the case and the present studies do not indicate that it is so. The only $H$. influenzae antibodies that have been shown to have a similar age-distribution to that of the bactericidal factor are those produced against a somatic antigen (Tunevall, 1953). That a somatic antigen could provoke protective antibody formation, in the rabbit at least, was demonstrated by Dubos (1942).

Observations in orphan homes where the carriage rate for $H$. influenzae type b is sometimes very high (Turk, 1963; Mpairwe, 1970) have suggested 
that in ordinary open communities, $H$. influenzae type $\mathrm{b}$ is rarely communicated from one household to another (Mpairwe). Hence only a very small proportion of children would be expected to have come into contact with this serotype by the age of $5 \mathrm{yr}$, and this might explain the low frequency of the capsular antibody in the present study. Yet from the age-incidence of $H$. influenzae type-b infections (Turk and May, 1967) it appears that by the age of 5 most children have already developed immunity. There would seem, therefore, to be a discrepancy between the rate at which immunity develops and that at which $H$. influenzae type $\mathrm{b}$ appears to circulate in these communities, suggesting that whatever it is that immunises against $H$. influenzae type b, it circulates faster than this serotype.

In view of this, the belief that the protective antibody against $H$. influenzae type $b$ is that produced against its capsular antigen-a belief that is largely based on analogies (Alexander; Davis et al.) between capsulated $H$. influenzae and capsulated pneumococci-may be erroneous.

\section{SUMMARY}

Sera were tested for capsular antibody and for bactericidal factor against Haemophilus influenzae type $b$. The age-distribution of the bactericidal factor corresponded to the known age-distribution of immunity to serious infection with $H$. influenzae type $\mathrm{b}$, but that of the capsular antibody did not. This finding argues against the belief that the protective antibody to $H$. influenzae type-b infections is that produced against its capsular antigen.

I am grateful to Professor E. Nnochiri who read the draft manuscript and offered valuable criticisms.

\section{REFERENCES}

Alexander, Hatrie E. 1965. The Hemophilus group. In Bacterial and mycotic infections of man, 4th ed., edited by R. J. Dubos and J. G. Hirsch, London, ch. 29, p. 724.

Collier, A. M., Connor, J. D., AND Nyhan, W. L. 1967. Systemic infection with Hemophilus influenzae in very young infants. J. Pediat., 70, 539.

Davis, B. D., Dulbecco, R., Eisen, H. N., Ginsberg, H. S., ANd Wood, W. B. 1967. Microbiology, London, ch. 27, p. 789.

Dubos, R. J. 1942. A soluble toxin produced by Hemophilus influenzae. J. Bact., 43, 77.

FothergILl, L. D., AND WRIGHT, J. 1933. Influenzal meningitis: the relation of age incidence to the bactericidal power of blood against the causal organism. J. Immun., 24, 273.

Jawetz, E., Melnick, J. L., AND Adelberg, E. A. 1966. Review of medical microbiology, 7th ed., Los Altos, pp. 221-223.

Macleod, C. M., AND Bernheimer, A. W. 1965. Pathogenic properties of bacteria. In Bacterial and mycotic infections of man, 4th ed., edited by R. J. Dubos and J. G. Hirsch, London, ch. 7, p. 146.

Mathies, A. W., JR, Hodgman, J., AND Ivler, D. 1965. Hemophilus influenzae meningitis in a premature infant. Pediatrics, Springfield, 35, 791.

MPAIRWE, Y. 1970. Observations on the nasopharyngeal carriage of Haemophilus influenzae type b in children in Kampala, Uganda. J. Hyg., Camb., 68, 337.

SmITH, M. H. D. 1956. Acute bacterial meningitis. Pediatrics, Springfield, 17, 258.

Tunevall, G. 1953. Studies on Haemophilus influenzae: a complement fixation test for Haemophilus influenzae antibody. Acta path. microbiol. scand., 32, 258. 
TuRK, D. C. 1963. Naso-pharyngeal carriage of Haemophilus influenzae type B. J. Hyg., Camb., 61, 247.

Turk, D. C., AND Green, C. A. 1964. Measurement of antibodies reacting with capsular antigens of Haemophilus influenzae. J. Clin. Path., 17, 294.

TURK, D. C., AND MAY, J. R. 1967. Haemophilus influenzae; its clinical importance, London, ch. 5 and 7.

WeInstein, L. 1946. Treatment of meningitis due to Haemophilus influenzae with streptomycin: report of 9 cases. New Engl.J. Med., 235, 101. 